\title{
Accommodating Difference? \\ British Trade Unions and Polish Migrant Workers
}

\author{
Phil James \\ Oxford Brookes University \\ and \\ Joanna Karmowska \\ Oxford Brookes University
}




\title{
Accommodating Difference? British Trade Unions and Polish Migrant Workers
}

\begin{abstract}
This article examines and evaluates the experiences of British unions in recruiting and organizing Polish migrant workers. It concludes that while British unions have been pursuing a range of relevant initiatives which seem to address key challenges confronting the recruitment and organization of such workers, these embody a number of significant weaknesses that must cast doubts over their long-term outcomes.
\end{abstract}

\section{Introduction}

Against the background of a dramatic decline in union membership, organization and recognition in Britain over the past three decades, a burgeoning literature has been developed on what unions can do to 'renew' or 'revitalize' themselves. At a risk of over simplification, this literature can be seen to encompass two, distinct, but not mutually exclusive, strands. First, a strand that focuses attention on the nature and potential value of a number of different 'generic' types of union strategies, such as 'partnership', 'organising', 'servicing', and diversity, social movement and community unionism (Heery, Healy and Taylor 2004; Cunningham and James, 2010). Secondly, one that centers on a consideration of the challenges unions face in expanding membership among particular under-represented categories of workers, such as part-timers, temporary workers, ethnic minorities, women and young people, and how these might be addressed 
(Healy and Kirton, 2000; Payne, 1989; Walters, 2002; Healy, Bradley and Mukherjee, 2004).

Recently, this second strand of work has expanded to encompass a greater focus of attention on the position of migrant workers. That it has done so is unsurprising given the extent of recent labour migration to the UK, notably as a result of the arrival of large numbers of migrant workers following the accession into European Union (EU) on 1 May 2004 of eight former communist countries - Czech Republic, Estonia, Hungary, Latvia, Lithuania, Poland, Slovakia, and Slovenia, henceforth referred to below, in line with common practice, as the 'A8' countries. Indeed, the inflow of workers from these countries in the period after accession was such that it made a substantial contribution to the largest ever in-migration to the country on record (Salt and Millar, 2006).

However, the importance of the new migrant community to the future of the British union movement extends beyond the simple fact of its current numerical size as a result of two further and related factors. First, the evidence available to indicate that propensity to unionize among young people is higher among those who come from a family background marked by pro-union sympathies (Blandon and Machin, 2003). Secondly, projections which suggest that not only will just under half of the UK population growth during the period 2006-2031 stem directly from net immigration, but a further $23 \%$ will arise indirectly from it (House of Lords, 2008). Thus, taken in conjunction with the size of the current migrant workforce, these factors serve to suggest that the union 
movement's future health is likely to be intimately connected to its ability to expand membership among it.

How such an expansion can best be achieved is therefore a question that is potentially of utmost importance to the union movement, particularly given that the challenges unions face in this area overlap with a number of the others that they are facing in the "new economy of work', including the difficulties of expanding union presence among SMEs, temporary workers and ethnic minorities more generally. The fact, nevertheless, remains that systematic knowledge about what British unions have been doing to recruit among the new migrant workforce, and with what effect currently, remains relatively limited, as does the literature more generally on the relationship between unions and migrant workers (McGovern, 2007).

Against this backcloth, the present article draws on a recent study of British trade union initiatives to expand membership and organization among Polish migrant workers. It does so with two related objectives in mind. The first of these is to use the findings to shed light on the nature of the initiatives currently being undertaken and union experiences of them. The second is to explore how far there are grounds for believing that the initiatives concerned provide a basis for achieving a substantial, and sustainable, expansion of union membership and organization among Polish migrants.

What follows is divided into four main sections. In the first, attention is paid to the opportunities and barriers to union recruitment and organization among Polish migrant 
workers in Britain. The next two then provide details of the methodology of the study drawn upon and its main findings. Finally, the fourth uses these findings to critically discuss the prospects of the British union movement securing a substantial, and sustainable, expansion of membership and organization among the Polish migrant workforce.

\section{British unions and Polish migrant workers: the opportunities and challenges}

There is no question that the British union movement nationally has acknowledged the importance of expanding recruitment and organization among migrant workers in general and Polish ones in particular. In the case of the latter, for example, the Trades Union Congress (TUC), the main union federation in Britain, has commissioned a number of studies of their labor market needs and positions, as well as the challenges and opportunities they provide to unions, and also supported a small number of regional projects focused more directly on improving union membership and organization among them (see e.g. Fitzgerald, 2006, 2007 and 2008; Fitzgerald and Hardy, 2010; Anderson, Ruhs, Rogaly and Spencer, 2006).

This focus of attention on the Polish migrant workforce can, at one level, be viewed as a logical progression of the TUC's long-standing anti-racism and -discrimination policies (Wrench, 2004) and opposition to immigration controls (Avci and McDonald, 2000;

Krings, 2009a). It can also, however, be seen more narrowly to be a reflection of a wider recognition that unions need to do more to organize among migrant workers and other 
'marginalized groups' (TUC, 2008). Indeed, it has been argued that the adoption of a relatively inclusive stance towards immigration on the part of the British union movement has itself been influenced by the fall in membership that it has experienced in recent decades and the awareness this has generated of the need to take more seriously the needs and interests of marginalized groups, including Black and Minority Ethnic (BME) ones (Wrench 2004).

At another level, however, the focus on Polish migrants can be seen to be a more straightforward pragmatic response to the sheer scale of the inward migration that occurred following the gaining of access to the United Kingdom labour market to workers from Poland, as well as the other 'A8' countries. An inward flow that, during the period May 2004 to December 2007, saw over 750,000 A8 nationals register for employment in the country, with by far the largest proportion coming from Poland (House of Lords, 2008).

Clearly, given its numerical size, the Polish migrant workforce offers a potentially fertile ground for union recruitment and organization. This is even more so when account is taken of clear evidence that many within it occupy relatively disadvantageous labour market positions and hence work in contexts that could well make the appeals of union membership attractive. Thus, the vast majority of recent A8 migrants have been found to be employed in low paying jobs on around the minimum wage (House of Lords, 2008), and in ones where working conditions more generally are often poor (McKay, Craw and Chopra, 2006). Indeed, there is clear evidence that significant numbers of them have been 
subjected to what can only be described more generally as exploitative conditions of employment (Citizens Advice Bureau, 2004; TUC, 2008). A point emphasized by the fact that Polish worker have constituted the largest national grouping of labour operating in the areas of employment governed by the Gangmasters Licensing Authority, namely agriculture, horticulture and associated processing and packaging industries (Geddes, Scott and Nielsen, 2007). This Authority having been established in 2006 to regulate labor standards within employment agencies operating in sectors where large numbers of temporary migrant workers were utilized and where concerns existed regarding the exploitation of such workers.

This potential for union recruitment, though, exists alongside Labour Force Survey data showing that actual union membership among Polish migrants is very low, standing at just over three percent (cited in Anderson, Ruhs, Rogaly and Spencer, 2006). It would therefore seem on the basis of available evidence that the British union movement has to date struggled, at the aggregate level, to achieve a substantial membership presence among them.

This low level of union penetration can be viewed as a product of a number of barriers that unions face in seeking to recruit and organize among the Polish migrant workforce. Barriers, or challenges, that can be linked to three categories of factors that the existing literature suggests influence significantly the joining behavior of potential union members (Turner, D'Art and O'Sullivan, 2008; Turner, D'Art and Cross, 2009). First, the extent to which union membership is available and encouraged via surrounding 
'social norms' (Green, 1990; Corneo, 1995). Secondly, the degree to which union membership is viewed as providing an effective means of addressing any existing sources of work-related grievances (Badigannavar and Kelly, 2005) and is seen as attractive in cost-benefit terms (Crouch, 1982). Thirdly, how far potential recruits understand the role of unions and are attitudinally supportive of this role.

The largest proportion of the Polish workforce is, for example, based in lowly unionized parts of the private sector, such as retail/hospitality, construction and 'other services' (Drinkwater, 2008). In addition, it would seem that a substantial proportion, perhaps over half, are in temporary employment (Home Office, 2008), a feature that points to the important role that, again largely non-unionized, employment agencies play in providing them with access to employment (Anderson, Clark and Parutis, 2006; Geddes et al, 2007).

The scope for unions to expand membership significantly through in-fill recruitment within workplaces where they are already recognized would consequently appear to be a very much constrained one. As a result, the achievement of such an expansion would seem to necessarily also require either the building up membership at the workplace level in the absence of already existing recognition or through 'beyond the enterprise' recruitment (Heery, Conley, Delbridge and Stewart, 2004). Sources of expansion that must themselves be viewed as problematic given how unions have struggled, even against the background of a statutory recognition procedure, to expand union organization within non-unionized workplaces in general, and in SMEs in particular 
(Kersley, Alpin, Forth, Bryson, Bewley, Dix and Oxenbridge, 2006), and the limited role that community and social movement unionism has so far played within British union renewal strategies (Perrett and Martinez Lucio, 2009; Wills and Simms, 2004). A limited usage that can, however, be noted to exist alongside evidence highlighting the important role that faith based organizations often play in providing support to low paid migrant workers (Datta, Mcllwaine, Evans, Herbert, May and Wills, 2007).

Such problematic features of the employment situation of Polish migrants, in turn, exist alongside a number of other factors which can pose problems to union organising attempts. At the time of registering for employment, for example, the majority of them expressed an, admittedly often subsequently changed, intention to stay for less than a year (Spencer, Ruhs, Anderson and Rogaly, 2007). A potentially important characteristic given evidence that the propensity of migrant workers to unionize is influenced by the length of time they have spent in the host country and the extent to which migration is viewed by them as being permanent (Waldinger and Der-Martirosian, 2000).

There are also concerns that their willingness to unionize could be adversely affected by the poor reputation that unions gained in Poland during the period of communist rule and the subsequent decline in the popularity of the Solidarity movement (Ost, 2006). In addition, the fact that the majority of them are relatively young, being mostly under the age of 35 and concentrated in the 16-25 age band (Drinkwater, 2008), can also be anticipated to be a potential source of difficulty. For, in the context of a low overall level of union membership density, only a very small percentage of this age range are members 
of unions in Poland, with the result that they are unlikely to have arrived with any prior contact, or direct understanding, of unions (Gardawski, 2002; Hardy and Fitzgerald, 2008; Ost, 2006).

Furthermore, the widespread need for language support identified among the recent migrants means that language, as well as cultural barriers would seem likely to confront attempts to challenge any adverse prior perceptions and understandings about the nature of British unions and the role that they play (Meardi, 2007; Fitzgerald, 2006). Potential barriers that more general research on the relationship between unions and minority groups indicates can subsequently further act to hinder their integration into union activities once they have joined (Greene and Kirton, 2003).

At the same time, however, all would not seem to be doom and gloom since there is also evidence to suggest that the extent of these potential sources of attitudinal and cultural problems should not be overstated. A survey undertaken on behalf of the TUC of Polish and Lithuanian workers who had requested a copy of a leaflet giving details of employment rights and the role of trade unions in their own language, for example, found that while just three percent of the 463 Polish respondents were union members, $54 \%$ of the total sample of 508 respondents stated that they would be interested in joining a union (Anderson, Clark and Parutis, 2006). A picture that is reinforced by the fact that in Irish survey of Polish migrant workers $37 \%$ of non-members reported that they would 'definitely' join a union if asked (Turner et al, 2008). 
In short, then, the numerical size of the Polish migrant workforce, its concentration in relatively low paying, and skilled, jobs, and evidence pointing to the not infrequent exposure of workers to exploitative employer behavior, suggest that it is a potentially fertile target for union recruitment and organization. That this is the case, however, exists alongside a very low level of current union membership and a number of potential barriers to union recruitment and organization. With these potential difficulties encompassing, as highlighted above, a frequent lack of immediate union availability, doubts regarding the ability of unions to resolve issues of concern at the workplace level, and attitudinal, awareness and language difficulties. Challenges and barriers which do, though, exist alongside some evidence suggesting that many Polish workers may, in principle, be supportive of unions and the idea of joining them.

\section{Methodology}

The data drawn upon here comes from three main sources, in-depth interviews with union staff, searches of the websites of the Trades Union Congress and those unions in which interviews were carried out, and a range of documentary evidence obtained from these websites and other sources. Some use was, however, also made of information gained from the websites of organizations concerned with migration related issues, attendance at several meetings connected to a migrant workers' branch established by the GMB union in Southampton, visits to a new multi-union learning project at Gatwick airport and informal discussions with staff and activists involved in this, and attendance at relevant 
conferences and seminars, and informal conversations with union officials and activists, as well as Polish migrants themselves, during the course of these.

The interviews and website searchers was conducted with a view to obtaining information on (a) the existence, and nature, of any specialist organizational units/positions that had been established to develop policy and/or coordinate activities in relation to the organization of migrant workers, (b) materials that had been prepared specifically for such workers, such as information about the union and its activities, and written advice about employment, social security and immigration rights, and how far these were available in languages other than English and (c) particular initiatives that had been undertaken to expand recruitment and organization among migrants, and the degree to which these had been successful.

In all, 28 interviews were undertaken. The decision to utilize interviews rather than adopt a survey based approach reflecting the exploratory nature of the research and the widely accepted view that such research, encompassing as it does 'why' and 'how' questions, is best pursued via the adoption of a qualitative approach (Saunders, Lewis and Thornhill, 1997: 74; Maylor and Blackmon, 2005: 140).

Those interviewed included a range of officials from a number of Britain's largest unions -Community, GMB, Unite - Transport and General Workers' Union (TGWU), Unite Amicus, Union of Construction, Allied Trades and Technicians (UCATT), UNISON and the Royal College of Nursing and, more particularly, project workers, organizers, several 
migrant worker activists directly involved in initiatives aimed at recruiting and organizing among Polish migrant workers. They also included the President of the Federation of Poles in Great Britain, an organization that it was found had been actively collaborating with a variety of unions, representatives from several Polish community groups, a manager from an employment agency involved in a collaborative partnership with Community in relation to the provision of English language provision for migrant workers, and the secretary of a Polish Catholic Centre that had been undertaking joint work with Unite- Amicus. The interviews carried out lasted between one and two and a half hours. All were recorded and subsequently transcribed for analysis.

In many respects therefore the findings reported below complement those reported in a recent paper by Fitzgerald and Hardy (2010) which also explored British union organizing strategies in respect of Polish migrant workers. First, by drawing on interviews from a wider range of unions and secondly by extending data collection to encompass not only relatively senior union officials, but also union organizers and project workers directly involved in initiatives aimed at migrant workers and several migrant worker activists. To reinforce this complementarity therefore, where quotes from interview transcripts are utilized in what follows they will be drawn from these different constituencies of interviewees.

\section{Findings}


The findings obtained through the above sources are initially detailed through an examination of the use made of different types of 'beyond the enterprise' activity. Attention then turns to the links between this activity and organising at the workplace level and the usage made of 'like for like' staffing and activism.

\section{Beyond the enterprise activity}

It emerged clearly from the data gathered that unions had undertaken a range of actions to raise their profile among the Polish migrant workforce, highlight the benefits that membership can bring and gain access to workers. It was also clear that they had done so because migrant workers in general were seen to represent a potentially important source of new membership, as the following quote from one of the union organizers interviewed illustrates:

'Nowadays, migrant workers represent a considerable part of our workforce. We will lose our voice in the workplace if they will not join us.'

This beyond the enterprise activity was found to have encompassed three main strands. The first of these comprised the making available of relevant information via publications and union websites. The TUC, for example, had secured agreement for those registering under the Worker Registration Scheme (WRS) to be provided with a pamphlet which covered all of the above issues and additionally produced this in a number of different languages, including Polish. In addition, it had also launched a website for Polish workers 
in their own language and produced a guide in conjunction with the Joint Council on the Welfare of Immigrants which, among other things, detailed the typical problems encountered by migrant workers and how unions can respond to them (TUC, 2002). Meanwhile, similar activities had been undertaken by most of the individual unions within which interviews were conducted.

The two other strands had involved supplementing such general awareness raising by seeking to gain access to Polish migrant workers through (a) the undertaking of educational initiatives, and (b) engaging with community groups and other organisations with an interest in the welfare of migrant workers.

\section{Education}

In recognition of the language problems faced by many migrant workers, interviewees revealed that unions had been commonly involved in providing English language classes to Polish migrants under the framework of the government funded English for Speakers of Other Languages (ESOL) Programme. These educational initiatives, although developed independently by different unions, were found to frequently encompass similar elements. Thus, they invariably provided, in addition to language tuition, other forms of support, such as help with CV writing and the provision of advice on housing and healthcare, and were utilized to distribute information on employment rights and the role and benefits of unions. In some cases they had also been supported by the establishment of community based learning centres where access could be gained to a wider range of 
training opportunities and more general union support and advice. Typically, such educational initiatives have been partly or wholly funded externally, for example, via the government financed Union Learning Fund, local authorities, regional development agencies, and Learning and Skills Councils.

An initiative undertaken in Community's South West region provides a typical illustration of this education based activity (Heyes, 2009). Here, Union Learning funds have been used to provide workers with free access to a 30 hour ESOL course and the possibility of subsequently taking a National City and Guilds qualification. These classes had additionally been used to provide information on the activities of the union and the benefits of joining it, and to also give participants advice and guidance on a range of work and non-work related matters, including in relation to housing, health care, schooling and possible future training and education that they could undertake. Interestingly, one of this project's 'stakeholders' was a temporary employment agency that utilized the language classes provided for its own staff.

Those interviewed who were directly involved in such educational initiatives invariably reported that they were meeting a real and important source of need among Polish workers. The following quote from a Polish project worker captures this view well:

'The Polish, we have different needs to indigenous workers and unions have to respond to this if they want to be attractive for us. We come here having nothing and not understanding much, we often don't speak a word of English. We need to settle first, 
learn the language, bring our families over, send children to school and we need help with all this.'

Such educational initiatives were further seen to be valuable in terms of the access they provided to migrant workers. A value, perhaps, most clearly demonstrated by the fact that a similar centre established in Southampton by the GMB was reported to have around 100 workers undertaking courses each week. It also appeared that, particularly via the provision of English language support, provided a useful means of overcoming communication and cultural barriers. Thus, a union organiser commented:

'A big barrier that unions have got in some areas is a language barrier. I can stand up and do this and that with hands, but then what we have done... with this project......is invaluable in relation to breaking down those barriers. And then the trust element builds up.'

\section{Engagement with community groups and other organisations}

A range of examples were identified of unions working with, or through, community based organisations, including the Federation of Poles in Great Britain, the Catholic Church, local authorities and regional development agencies.

In the North West of the country, for example, the regional development agency was found to have provided financial assistance to support the establishment of a charitable 
body, Migrant Workers North West, by Unite - TGWU to collate and promote 'best practice' in the employment of migrant workers and the provision of support to migrant workers communities. Meanwhile, a number of unions, including Unite - TGWU, GMB, UCATT and Unite - Amicus, were also found to have organised joint meetings with the above mentioned federation, as well as local Polish community groups. The President of this federation commented on the motives for working with trade unions and the benefits it brought to them in the following terms:

'We, as a Polish community organisation, don't have enough expertise or enough money to defend individuals..... But without doubt, our field of activity is to persuade Poles to join unions..... Simply, they don't know how to approach Polish people, they don't know what to say, they don't know how to encourage them. Maybe, the best or the worst example of that was one union, which is very active among people working in hotels. And they wanted to organize a meeting for hotel workers..... They provided a very good lunch for everybody, they paid for renting the room, they spent lots of money and there were only three people who turned up for the meeting...... We organized a meeting in the same place, a month later, with a much smaller trade union. We didn't offer anything to people who were coming except help and information, and we had over 200 people who turned up. So there is a difference.'

Such meetings were seen to have invariably provided unions with a valuable means of accessing Polish migrant workers to explain what they do and the benefits of joining. For 
example, a joint meeting with Unite-Amicus in Bradford, at which advice was given on a range of issues, including housing and social services, and information provided on how to join unions and the benefits of doing so, was reported to have attracted around 400 people. Similarly, a public meeting organised by the GMB in Southampton, as a result of contacts with the local Polish community, was attended by 120 workers and led not only to the recruitment of new members but to a subsequent decision to set up a new union branch (see below).

A number of examples were also identified of various forms of local involvement with the Catholic Church in campaigns and joint meetings. Perhaps the most developed of these collaborations was that between Unite - Amicus in the Yorkshire and Humberside area. Here, the union had established a close working relationship with the Polish Catholic Centre in Leeds which, among other things, encompassed the provision of financial support and articles for the Centre's newspaper, as well as ESOL and other educational classes, and the running every six weeks of joint union-church meetings in different parts of the region; as well as a union presence each Sunday before and after mass.

\section{Workplace organising and beyond the enterprise activity}

Unions were, as with the educational initiatives already detailed, reported to be using their engagement with community groups and other organisations to identify workplaces and employers where organising activity could be undertaken. At the same time, 
however, only a limited number of concrete examples were identified where this 'beyond the enterprise' activity had contributed directly to such organising activity.

One such example was the already mentioned educational collaboration between Community and a temporary employment agency which had extended to encompass the circulation internally of union leaflets, the creation of a noticeboard that could be used to promote the union and the more general encouragement of union membership by the agency when workers registered with it. Another was a campaign aimed at a major flower company within GMB's Southern region which had led to the obtaining of representation rights and the eventual hope of recognition being secured.

No examples were therefore found of recognition campaigns being conducted on the basis of the type of comprehensive organising advocated in the U.S 'new labor movement' literature (Milkman and Voss, 2004; Sherman and Voss, 2000; Voss and Sherman, 2003; Milkman, 2006), beyond the already well reported ones of TELCO's Living Wage Campaign in East London and the Unite - TGWU led Justice for Cleaners Campaign (Wills, 2002; TUC, 2008) - the latter of which it can be noted has been very much influenced by the U.S Justice for Janitors one (Erickson, Fisk, Milkman, Mitchell and Wong, 2002).

Where unions were recognised in workplaces containing substantial numbers of migrant workers, cases were reported of English language provision being used as a means of encouraging union membership. For example, in relation to a major bus company, 
reference was made to how Unite - TGWU were using in-house learning centres in this way in respect of the large number of Polish bus drivers that the company had employed. In a similar vein, a UNISON interviewee reported how such language classes were being provided for Eastern European workers employed by a cleaning services company within which the union had recognition. There were, though, signs that difficulties could exist at the workplace level regarding the offering services to non-member migrant workers as an inducement to become a member because of the use of income derived from existing members for this purpose. An issue that the following quote from a union branch official (activist) in response to a question asking about whether training was being provided to non-members within a particular work site illustrates well:

'No, not necessarily, what we do is we supply initial advice to people. What we say to people is look, your not a union member, we've got our existing members......... and I think to a certain extent if you're a member your buying into something.....You have to be a bit careful sometimes, you can go into it too far and I could have a member coming up to me saying, well hang on a minute.....'

\section{'Like for like' recruitment}

There was a general agreement among interviewees that effective organising among migrant workers requires due account to be taken of relevant language and cultural barriers. One particular challenge noted in this regard was the way in which such workers 
can be suspicious of unions, or unwilling to engage with them, because of the close relationships that had existed under the period of communist rule between unions and government in Poland. Another was the way in which their engagement with, and participation in, the activities of union branches could be problematic because of language limitations and the difficulties that could arise as a result of the way in which meetings of them are conducted. For example, in relation to such difficulties one migrant worker activist observed the following:

'After the first six months of membership I almost gave-up because I couldn't really follow what was talked about. It all seemed to be in code to me, using abbreviations, and... what is it called... acronyms? Well, in the end I persevered and now I'm glad I did so. Gaining understanding seemed to also gain me acceptance.'

To address these language and cultural barriers a number of examples were identified of joint working with Polish unions. At the level of the TUC, for example, collaboration with Solidarnosc was found to have led to the appointment of a full-time organiser from the latter in the North West region and the involvement of another organiser in a collaborative project involving the Northern TUC, UCATT and Northumbria University centred on the North East construction industry (Fitzgerald, 2006). Meanwhile, at the level of individual unions, UNISON had cooperated with OPZZ, another Polish union, on overcoming cultural barriers to organising in Polish communities and the GMB had concluded an agreement with Solidarnosc under which the latter undertook to set up a website for Polish workers informing them of their employment rights, the benefits of 
joining an union and how they could join the GMB, including before they even left Poland (GMB, 2007).

Virtually all of the unions also provided examples of Polish organisers and project workers having been appointed against the backcloth of evidence pointing to the potential value of 'like for like' organising (Holgate, 2005). These included the presence of two Polish members of staff in Unite - TGWU's North West region's organising unit, the employment of a Polish liaison worker to support the earlier mentioned Community educational initiative, and the similar use of staff in the GMB's Southern region.

A number of interviewees further alluded to the importance of encouraging members from migrant groups to not only become members but also activists, with one interviewee observing, for example, that 'migrant workers are more likely to join a union within which migrants are active' and another commenting in relation to this that: 'It is logical as I see it, we all prefer someone we identify with. English identify with English, Poles with Poles, and so on...'. In several unions such considerations had led to the adoption of initiatives specifically aimed at increasing the number of migrant union activists. The GMB Southern Region, for example, had developed an activist course for migrant workers aimed at encouraging the union's approach to self-organising, and another focussing on the challenges that union officers face in both servicing and organising migrant workers (GMB, 2008). Meanwhile, nationally within UNISON a Migrant Workers Participation Project had been established with financial support from the then government financed Union Modernisation Fund to develop initiatives in this area and 
thereby support the union's constitutional objective of ensuring that representation at all levels of the union is proportionately representative of its membership.

Several examples were, in turn, found where unions had decided to pursue this logic to the point of organising Polish members into geographical based migrant worker branches that were supported by Polish speaking staff. Community's South West regional educational initiative had, for example, led to the establishment of such a branch in Yeovil. Similarly, a branch of this type had been set up in the GMB's Southern region in Southampton (Labour Research Department, 2007).

\section{Discussion}

In the recent article by Fitzgerald and Hardy (2010) referred to earlier, attention was drawn to how British unions had sought to recruit and organise among Polish migrant workers using a range of innovative strategies and via the establishment of new local, regional, national and internationals collaborations. At the same time, while noting that such alliances and networks had been highly successful in engaging and recruiting 'A8' migrant workers, the authors expressed concerns about their scale and sustainability, pointed to the way in which the sustainability of the strategies adopted was threatened by resource constraints; highlighted how unions faced potential criticism from indigenous workers that their interests were being neglected, noted that disagreement existed as to whether migrant workers should be treated as a separate group; and reported concerns within unions about whether those recruited would prove to be 'cost-effective to service'. 
In many respects, as the following discussion will demonstrate, the findings from the present study, based as they are on data from a larger sample of unions, which excluded some of those included in Fitzgerald and Hardy's study, can be seen to reinforce and therefore add weight to most of these observations. They do, though, also appear to raise greater concerns about both the sustainability financially of many initiatives and of the membership gains made as a result them. In doing so, they further suggest that unions still face major challenges in providing recently recruited migrant workers with an ongoing incentive to remain in membership when recruited above the workplace level.

The findings reported above demonstrate, for example, that some of Britain's largest unions have been engaged in a variety of initiatives aimed at supporting the recruitment and organisation of Polish migrant workers, confirming evidence reported elsewhere as to what unions have been doing in this regard (see e.g. Martinez Lucio and Perrett, 2009; Heyes, 2009). Taken together, they further show that the initiatives being pursued could be seen to broadly address the main challenges and barriers that were identified earlier as potentially confronting the recruiting and organising of such workers.

The lack of availability of unions to migrant workers at the workplace level had been addressed by attempts to access them, often via community organisations, at the 'beyond the enterprise' one and to utilise this access to identify their most pressing needs and concerns and possible opportunities for successful workplace organising. Unions were, also found to have sought to demonstrate their value to workers at this level through the provision of educational opportunities, notably, but not exclusively, in the form of ESOL 
classes, and other forms of both employment and non-employment based advice and support.

Efforts had also been made to use the contact established with Polish migrants to explain the nature of British trade unions and the benefits that membership of them can bring, and thereby challenge any barriers to joining stemming from a lack of knowledge of unions or adverse prior perceptions of them arising from their current and previous role in Poland. A process that had at times facilitated by the use of 'like for like' recruitment encompassing Polish (speaking) staff and project workers, and the collaborative involvement of 'trusted' community based organisations. And which has, in a few cases, had been extended to encompass the establishment of migrant workers' branches that were intended to both support 'self-organisation' and overcome language and cultural barriers confronting their engagement with 'normal' ones.

Also on a positive note, based on their experiences, interviewees, while acknowledging the challenges involved, generally felt that Polish migrant workers, particularly younger ones, were very much organisable. Although this was a view which, with the notable exception of the GMB's migrant workers' branch in Southampton, was found to be generally difficult to validate by reference to hard recruitment data.

These positive observations regarding what British unions have been doing to recruit and organise among Polish migrant workers, though, need to be balanced against a number of problematic features of this activity. Features which serve to raise important questions 
regarding the sustainability of many of the identified initiatives and the membership gains obtained as a result of them.

Much of the activity identified, notably in the educational area, essentially encompassed the servicing of important, but essentially immediate, individual needs at a 'beyond the enterprise' level. As a result, the question inevitably arises as to whether membership will remain an attractive option once these needs have been met, particular given the doubts that have been expressed more generally as to whether educational initiatives, even when undertaken at the workplace level, provide an effective source of 'union renewal' (Mcllroy, 2008).

These concerns, in turn, can be seen to receive further reinforcement from the premises of mobilisation theory (Badigannavar and Kelly, 2005) and evidence which suggests that people often decide to join unions, and remain members of them, as a protective investment in case they 'have a problem at work' (Waddington and Whitson, 1997). Thus, in the light of the generally limited evidence obtained of successful workplace organising having stemmed from such servicing activity, doubt necessarily arises about the extent to which membership continuity can be achieved in the absence of workplace representative arrangements capable of providing such protection and more generally engendering collective solidarity. 
The resourcing and more general 'governance' of the recruitment and organising initiatives identified also serves to raise other important questions about their sustainability.

A common feature of many of them was their reliance on, often short-term, external funding from such sources as local authorities, local Learning and Skills Councils, regional development agencies, the Union Learning Fund, the Union Modernisation Fund, and the ESOL program. Another, in the case of those undertaken by individual unions, was the local nature of their 'authorship'.

Such reliance on external funding raises obvious concerns about the on-going sustainability of many of the identified initiatives; concerns that were given added weight in the findings above by the way in which changes to the funding of the ESOL program had already acted to threaten the future of some of the language training provided. The same is true of the devolved origins of much of the activity concerned since not only was the extent to which it was the subject of wider and likely longer-term support at higher union levels generally unclear, but there were also indications that this support was at times problematic.

Overall, then, the picture to emerge from the findings obtained suggests that while a good deal of impressive work has been done across the country by unions to recruit and organize Polish workers, the financial sustainability of much of it would seem open to question, the scale of the membership gains obtained is, for the most part, far from clear, 
and doubts must exist as to whether these gains are themselves sustainable. Such reservations it has to be acknowledged may prove to be misplaced. Insofar as this is not the case, however, they beg the question of how unions should respond to them.

Clearly one response would be for unions to focus their own internal resources in terms of staffing and expenditure more on initiatives to organise among migrant workers so that those undertaken are less reliant on vulnerable sources of external funding. This in itself, however, would leave unresolved the wider and more fundamental issue of how membership gains achieved through initiatives of the type detailed in this paper can be effectively sustained.

Existing evidence on union member joining, as highlighted earlier, points to the importance of workers perceptions of the role that joining a union can play in protecting and enhancing their interests. In doing so it indicates that member retention is intimately connected to the existence of an ongoing nexus between union membership and interest representation. Given the doubts raised about the sustainability of recent membership among Polish migrants, there would seem a need for British unions to improve this nexus so that it extends beyond the addressing of needs, such as housing advice and English language support, associated with being a 'recent migrant' to incorporate a wider range of 'individual benefits' (Bassett and Cave, 1993) . Even if this is financially and organizationally viable, however, evidence does not lend much support to the likely value of such an approach (Kelly and Waddington, 1995; Williams, 1997). 
If this pessimistic conclusion is correct, then the challenge for unions would seem to be finding a way to create a much more strategic linkage between 'beyond the enterprise organising activity' and the representation of workers interests at the workplace level - so that initiatives at the first of these levels move beyond a focus on 'recruitment' to form an integral part of a strategy aimed at the representation of the substantive employmentrelated interests of workers. In this regard, the wider adoption of many of the prescriptions of the U.S 'new labor movement' literature reviewed earlier would clearly seem potentially relevant. This is, moreover, perhaps particularly so with regard to the advocacy in it of organising migrants on an 'occupational', rather than 'generic', as with the Justice for Janitors campaign. For such a focus clearly opens up a greater potential to link recruitment outside of the workplace to a concerted approach to achieving representation within the workplace.

A strategic re-orientation of this type would, however, still leave unions in Britain confronting major barriers with regard to the achievement of workplace representation (and recognition), notably employer opposition to union organising and recognition. A further line of needed response would therefore seem to be the exerting of pressure for legal reforms supportive of its achievement.

In the space available, it is not possible to provide a detailed consideration of the precise reforms that could and should be pursued in this area given that they potentially encompass improvements to the present statutory framework for union recognition (Ewing, Moore and Wood, 2003), the creation of stronger anti-discrimination protection 
for union members and the introduction of legal requirements on the establishment in non-union workplaces of elective consultative bodies that could potentially support collectivization and the building of union membership. Two, somewhat related, avenues of reform do, though, merit specific mention given their very direct relevance to the above argument relating to the creation of stronger linkages between 'beyond the enterprise' recruitment and workplace representation.

The first of these concerns the exerting of pressure, in conjunction with migrant workers and community groups, to establish forms of supply chain regulation that incorporate labor standards (including rights to union representation and recognition) in sectors where migrant workers are concentrated and impose a duty on major supply chain actors to monitor compliance with them (James, Johnstone, Quinlan and Walters, 2007; Weil and Mallo, 2007). The second, the introduction of union rights to 'follow recruited members' into their employing organization, thereby providing unions with a means of both pursuing the interests of migrant members who have been recruited from outside of the workplace level and building collective solidarity and pressure for employer recognition: an approach that, in the Australian context, has been observed to have provided unions 'with unique recruitment opportunities at the shopfloor level' (Pyman, 2004: 2).

\section{Conclusion}


Against the backcloth of a large inflow of Polish migrant workers since 2004, this article has examined the nature, and experiences, of union initiatives to recruit and organize such workers, and explored how far they appear to provide a basis for a substantial, and sustainable, expansion of membership and organization among them. In doing so, it has revealed that a range of initiatives have been undertaken in pursuit of this objective and that these do broadly address the main barriers which the existing literature suggests confront its achievement.

At the same time, while those interviewed generally felt, on the basis of their experiences, that Polish migrants were very much organizable, concrete evidence of union achievement in this regard was found to be relatively limited. In addition, a number of grounds for casting doubt on the sustainability of many of the initiatives, as well as the membership gained as a result of them, were identified, perhaps most notably a lack of a strong connection with effective workplace organising and an over reliance on external, often short term, funding. This doubt was, in turn, identified as potentially requiring unions to re-appraise their current approaches to the recruitment and organization of such workers. In particular, it has been suggested that these approaches need to encompass a stronger 'occupational' focus that is facilitative of the creation of stronger linkages between recruitment at beyond the workplace and the provision of workplace representation. It has been further suggested that this re-orientation needs to be supported by the pursuit of supportive legal reforms, most notably ones that provide unions with increased rights to access to workplaces in which they are not recognised but have members. 


\section{References}

Anderson, B., Ruhs, M., Rogaly, B. and Spencer, S. (2006) Fair Enough? Central and East European Migrants in Low-wage Employment in the UK. Oxford: Oxford University Centre on Migration, Policy and Society.

Anderson, B., Clark, N. and Parutis, N. (2006) New EU Members? Migrant Workers' Challenges and Opportunities to UK Trades Unions: A Polish and Lithuanian Case Study. Oxford: Oxford University Centre on Migration, Policy and Society.

Avci, G. and McDonald, C. (2000) Chipping away at the Fortress: Unions, Immigration and the Transnational Labour Market. International Migration, 38, 2, 191-213.

Badigannavar, V. and Kelly, J. (2005) Why are Some Union Organising Campaigns more Successful than Others? British Journal of Industrial Relations, 43, 3, 515-535.

Bassett, P. and Cave, A. (1993) All for one: The future of unions. London: Fabian Society.

Blandon, J. and Machin, S. (2003) Cross-generation Correlations of Union Status for Young People. British Journal of Industrial Relations, 41, 3, 391-415.

Citizens Advice Bureau (2004) Nowhere to Turn: CAB Evidence on the Exploitation of Migrant Workers. London: CAB.

Corneo, G. (1995) Social Custom, Management Opposition and Trade Union Membership. European Economic Review, 39, 275-292.

Cunningham, I. and James, P. (2010) Strategies for Union Renewal in the Context of Public Sector Outsourcing. Economic and Industrial Democracy, 31(1), 34-61.

Crouch, C. (1982) Trade Unions: The Logic of Collective Action. London: Fontana.

Datta, K., McIlwaine, C., Evans, Y., Herbert, J., May, J. and Wills, J. (2007) From Coping Strategies to Tactics: London's Low-pay Economy and Migrant Labour. British Journal of Industrial Relations, 45, 2, 404-432.

Drinkwater, S. (2008) Memorandum of Evidence, in House of Lords, The Economic Impact of Immigration - Volume 2: Evidence. HL Article 82-II. London: Stationary Office. Available at: http://www.publications.parliament.uk/pa/ld200708/ldselect/ldeconaf/82/7111305.htm, retrieved 12.08.2011. 
Erickson, C., Fisk, C., Milkman, R., Mitchell, D. and Wong, K. (2002) Justice for Janitors in Los Angeles: Lessons from Three Rounds of Negotiations. British Journal of Industrial Relations, 40, 3, 543-567.

Ewing, K., Moore, S. and Wood, S. (2003) Unfair Labour Practices: Trade Union Recognition and Employer Resistance. London: Institute of Employment Rights.

Fitzgerald, I. (2006) Organising Migrant Workers in Construction: Experience from the North East of England. London: TUC.

Fitzgerald, I. (2007) Working in the UK: Polish Migrant Worker Routes into Employment in the North East and Northwest Construction and Food Processing Sectors. London: TUC.

Fitzgerald, I. (2008) A Moving Target: The Informational Needs of Polish Migrant Workers in Yorkshire and the Humber. Leeds: Yorkshire and Humber TUC.

Fitzgerald, I. and Hardy, J. (2010) 'Thinking Outside of the Box?' Trade Union Organizing Strategies and Polish Migrant Workers in the United Kingdom. British Journal of Industrial Relations, 48, 1, 131-150.

Gardawski, J. (2002) Declining Trade Union Density Examined. Dublin: European Foundation for the Improvement of Living and Working Conditions.

Geddes, A., Scott, S. and Nielsen, S. (2007) Gangmasters Licensing Authority Evaluation Study: Baseline Report. Nottingham: Gangmasters Licensing Authority.

GMB (2007) GMB and Solidarnosc Link Up To Stop Exploitation Of Polish Migrant Workers In The UK. http://www.gmb.org.uk/Templates/PressItem.asp?NodeID=95002, retrieved 27.09.2007.

GMB (2008) Migrant Workers Update. http://www.gmbsouthern.org.uk/default.asp?pageid $=75 \&$ mpageid $=22 \&$ groupid $=3$, retrieved 14.04.2008.

Greene, A.-M. and Kirton, G. (2003) Possibilities for Remote Participation in Trade Unions: Mobilising Women Activists. Industrial Relations Journal, 34, 4, 319-333.

Green, F. (1990) Trade Union Availability and Trade Union Membership in Britain. The Manchester School, 58, 4, 378-394.

Hardy, J. and Fitzgerald, I. (2008) Cross Border Trade Union Collaboration in the Context of Competition and Arbitraging Labour in an Enlarged Europe, paper presented at ESRC Research Seminar Series 'Changing Cultures of Competitveness', University of Manchester, July. Available at:

http://northumbria.openrepository.com/northumbria/bitstream/10145/129065/1/Fitzgerald cross\%20Border\%20Trade\%20Union\%20Collaboration.pdf, retrieved 12.08.2011. 
Healy, G. and Kirton, G. (2000) Women, Power and Trade Union Government in the UK, British Journal of Industrial Relations, 38, 3, 343.

Healy, G., Bradley, H. and Mukherjee, N. (2004) Individualism and Collectivism Revisited: A Study of Black and Minority Ethnic Women, Industrial Relations Journal, $35,451-466$.

Heery, E., Healy, G. and Taylor, P. (2004) Representation at Work: Themes and Issues. in G. Healy, E. Heery., P. Taylor and W. Brown (eds), The Future of Worker Representation. 1-36. Basingstoke: Palgrave.

Heery, E., Conley, H., Delbridge, R. and Stewart, P. (2004) Beyond the Enterprise: Trade Union Representation of Freelancers in the UK. Human Resource Management Journal, $13,2,20-35$.

Heyes, J. (2009) Recruiting and Organising Migrant Workers through Education and Training: A Comparison of Community and GMB. Industrial Relations Journal, 40, 3, 182-197.

Holgate, J. (2005) Organising Migrant Workers: A Case Study of Working Conditions and Unionization in a London Sandwich Factory. Work, Employment and Society, 19, 3, 463-480.

Home Office (2008) Accession Monitoring Report May 2004 - May 2008. Home Office, Department for Communities and Local Government, HM Revenue and Customs, Department for Work and Pensions.

House of Lords (2008) The Economic Impact of Immigration - Volume 1: Report. HL Paper 82-I. London: Stationary Office. Available at:

http://www.publications.parliament.uk/pa/ld200708/ldselect/ldeconaf/82/82.pdf, retrieved 12.08.2011.

James, P., Johnstone, R., Quinlan, M. and Walters, D. (2007) 'Regulating Supply Chains to Improve Health and Safety'. Industrial Law Journal, 36, 2, 163-187.

Kelly, J. and Waddington, J. (1995). New prospects for British Labour. Organisation, 2(3), 415-426.

Kersely, B., Alpin, C., Forth, J., Bryson, A., Bewley, H., Dix, G. and Oxenbridge, S. (2006) Inside the Workplace: Findings from the 2004 Workplace Employment Relations Survey. London: Routledge.

Krings, T. (2009a) A Race to the Bottom? Trade Unions, EU Enlargement and the Free Movement of Labour. European Journal of Industrial Relations, 15, 1, 49-69. 
Krings, T. (2009b) Organised Labour and Migration in the Global Age: A Comparative Analysis of Trade Union Responses to Migrant Labour in Austria, Germany, Ireland and the UK. Unpublished PhD thesis, Dublin City University. Available at http://doras.dcu.ie/14848/2/Torben_Krings_Final_Thesis.pdf

Labour Research Department (2007) Polish Workers Make History. Labour Research, May.

Martinez Lucio, M. and Perrett, R. (2009) The Diversity and Politics of Trade Unions, Responses to Minority Ethnic and Migrant Workers: The Context of the UK. Economic and Industrial Democracy, 30, 3, 324-347.

Maylor, H. and Blackmon, K. (2005) Researching Business and Management. Basingstoke: Palgrave Macmillan.

Milkman, R. (2006) L.A. Story: Immigrant Workers and the Future of the U.S. Labour Movement. New York: Russell Sage Foundation.

Milkman, R. and Voss, K. (2004) Organising and Organizers in the New Union Movement. Ithaca: Cornell University Press.

McGovern, P. (2007) Immigration, Labour Markets, and Employment Relations: Problems and Prospects. British Journal of Industrial Relations, 45, 2, 217-235.

McKay, S., Craw, M. and Chopra, D. (2006) Migrant Workers in England and Wales: An Assessment of Migrant Worker Health and Safety Risks. Sudbury: Health and Safety Executive.

Mcllroy, J. (2008) Ten Years of New Labour: Workplace Learning, Social Partnership and Union Revitalisation in Britain. British Journal of Industrial Relations, 46, 2, 283313.

Meardi, G. (2007) The Polish Plumber in the West Midlands: Theoretical and Empirical Issues. Review of Sociology, 13, 2, 39-56.

Ost, D. (2006) The Defeat of Solidarity. Ithaca: Cornell University Press.

Payne, J. (1989) Trade Union Membership and Activism among Young People in Britain. British Journal of Industrial Relations, 27, 1, 111-132.

Perrett, R. and Martinez Lucio, M. (2009) Trade Unions and Relations with Black and Minority-Ethnic Community Groups in the United Kingdom: The development of New Alliances? Journal of Ethnic and Migration Studies, 35, 8, 1295-1314.

Pyman, A. (2004) Union Rights of Entry: The New Contested Terrain? Working Paper Series, 14 (4), Monash University Department of Management, Melbourne. 
Salt, J. and Millar, J. (2006) Foreign Labour in the United Kingdom: Current Patterns and Trends. Labour Market Trends, October, 335-353.

Saunders, M., Lewis, P. and Thornhill, A (1997) Research Methods for Business. London: Pitman Publishing.

Sherman, R. and Voss, K. (2000) Organise or Die: Labor's New Tactics and Immigrant Workers, in Organizing Immigrants: The Challenge for Unions in Contemporary California, 81-108. Ithaca: Cornell University Press.

Spencer, S., Ruhs, M., Anderson, B. and Rogaly, B. (2007) Migrant Lives Beyond the Workplace: The Experiences of East and Central Europeans. London: Joseph Rowntree Foundation.

Trades Union Congress (2002) Migrant Workers - A TUC Guide. London: Trades Union Congress.

Trades Union Congress (2008) Hard Work, Hidden Lives: The Full Report of the Commission on Vulnerable Employment. London: Trades Union Congress.

Turner, T., D’Art, D. and O’Sullivan, M. (2008) Union Availability, Union Membership and Immigrant Workers: An Investigation of the Irish Case. Employee Relations, 30, 5, 479-493.

Turner, T., D'Art, D. and Cross.C (2009) Polish Workers in Ireland: A Contented Proletariat? Labor Studies Journal, 34, 1, 112-126.

Voss, K. and Sherman, R. (2003) You Just Can't Do It Automatically: The Transition to Social Movement Unionism in the United State. in P. Fairbrother and C. Yates (eds) Trade Unions in Renewal: A Comparative Study, 51-77. Abingdon: Routledge. Waddington, J. and Whitson, C. (1997) Why do People Join Unions in a Period of Membership Decline? British Journal of Industrial Relations, 35, 4, 515-546.

Waldinger, R. and Der-Martirosian, C. (2000) Immigrant Workers and American Labour: Challenge...... or Disaster? in R. Milkman (ed) Organizing Immigrants: The Challenge for Unions in Contemporary California, 49-74. Ithaca: Cornell University Press.

Walters, S. (2002) Female Part-time Workers' Attitudes to Trade Unions in Britain. British Journal of Industrial Relations, 40, 1, 49-68.

Weil, D. and Mallo, C. (2007) 'Regulating Labour Standards via Supply Chains: Combining Public/Private Interventions to Improve Workplace Compliance. British Journal of Industrial Relations, 45, 4, 805-828.

Williams, S. (1997) The nature of some recent trade union modernization policies in the UK. British Journal of Industrial Relations, 35(4), 495-514. 
Wills, J. (2002) Union Futures. London: Fabian Society.

Wills, J. and Simms, M. (2004) Building Reciprocal Community Unionism in the UK. Capital and Class, 82, 59-84.

Wrench, J. (2004) Trade Union Responses to Immigrants, and Ethnic Inequality in Denmark and the UK: The Context of Concensus and Conflict. European Journal of Industrial Relations, 10, 1, 7-30. 